\title{
Microbiome Alterations Are Correlated with Occurrence of Postharvest Stem-End Rot in Mango Fruit
}

Sonia Diskin, Department of Postharvest Science of Fresh Produce, Agricultural Research Organization, Volcani Center, Bet Dagan 50250, Israel; and Department of Plant Pathology and Microbiology, The Robert H. Smith Faculty of Agriculture, Food and Environment, The Hebrew University of Jerusalem, Rehovot 76100, Israel; and Oleg Feygenberg, Dalia Maurer, Samir Droby, Dov Prusky, and Noam Alkan, ${ }^{\dagger}$ Department of Postharvest Science of Fresh Produce, Agricultural Research Organization, Volcani Center, Bet Dagan 50250, Israel

Accepted for publication 16 July 2017.

\section{ABSTRACT}

During storage and ripening, mango fruit develop stem-end rots (SER) that reduce quality, causing significant losses of harvested fruit. The presented results indicate that pathogens, endophytically colonizing the fruit's stem end, awaken during fruit ripening and cause SER. The main pathogens causing SER in mango grown in Israel were found to be Alternaria alternata and Lasiodiplodia theobromae. Confocal analysis of the sliced stems indicated that the pathogens endophytically colonize the phloem of the fruit's stem end; they branch into the fruit parenchyma when the pathogen switches to its actively pathogenic stage. We show that the stem ends are also colonized by other microorganisms, including fungi, yeast, and bacteria, which do not cause any apparent symptoms and are considered as true endophytes. Stem-end microbiomes of red (resistant) compared with green (susceptible) mango stored at optimal and suboptimal temperatures were deep sequenced for fungi and bacteria using internal transcribed spacer and 16S, respectively. Our results showed that both fungal and bacterial community changes are dependent on fruit peel color, storage duration, and storage temperature. The stem-end microbiota seems to be very dynamic in terms of interactions and changes. For example, in susceptible fruits, as green mango compared with red mango and in fruit after storage compared with harvested fruit, the abundance of Alternaria (Pleosporaceae) pathogens increased. This increase in pathogenic fungi was correlated with the increased occurrence of SER. In those two scenarios, before the rot developed, the increased amount of fungi was correlated with an increased abundance of chitin-degrading Chitinophagaceae bacteria. In summary, our results show that various conditions modify the microbial community at the stem end and can reduce postharvest SER.

Additional keywords: agriculture, anthocyanin, plant pathology.
Overall postharvest losses of fruit and vegetables are estimated at 30 to 50\% (Henningsson et al. 2004; Terry et al. 2011), with postharvest fruit rot being one of the major causes. In recent years, there has been a rising demand by customers for ripe and ready-toeat fruit. Thus, there is an increased need to maintain ripe fruit for longer periods of time. However, ripe fruit are more susceptible to, among others, stem-end rot (SER) pathogens (Prusky et al. 2013).

SER is considered to be the second most severe disease in mango fruit, the first being anthracnose caused by Colletotrichum gloeosporioides Penz. (Prusky et al. 2009). In 2014 in Israel, SER caused

${ }^{\dagger}$ Corresponding author: N. Alkan; E-mail: noamal@volcani.agri.gov.il

*The $\boldsymbol{e}$-Xtra logo stands for "electronic extra" and indicates that eight supplementary figures are published online.

This article is in the public domain and not copyrightable. It may be freely reprinted with customary crediting of the source. The American Phytopathological Society, 2017. about $30 \%$ loss of harvested mango fruit. SER can be the major cause of postharvest losses in mango fruit, particularly when anthracnose (C. gloeosporioides) that causes decay on the peel is well controlled (Johnson et al. 1991, 1992a), as in areas where the fruit is harvested during a dry season (Prusky et al. 2009). However, only a few studies have been conducted on stem-end pathogens. The SER pathogens of mango include Alternaria alternata and C. gloeosporioides (Johnson et al. 1992a; Prusky et al. 2009), and various Botryosphaeria-related species such as Dothiorella dominicana, Dothiorella mangiferae, Lasiodiplodia theobromae, Neofusicoccum sp., Phomopsis mangiferae, Cytosphaera mangiferae, and Pestalotiopsis sp. (Johnson et al. 1992a). SER pathogens penetrate the stem through natural openings (stomata, lenticels) and wounds (Johnson et al. 1992a). The causal agents of SER can live endophytically in the stem tissue of mango trees until the fruit are harvested and ripen (Johnson et al. 1992b; Prusky et al. 2009, 2013). As the fruit ripens, many physiological changes occur. The pathogens sense these changes and respond to them by switching from an "endophytic-like stage" to a devastating necrotrophic stage, when 
the fungi cause SER (Johnson et al. 1992b; Prusky et al. 2009, 2013). The SER-causing pathogens are accompanied by various endophytic microorganisms such as bacteria, yeast, and fungi that colonize the tree stems (Porras-Alfaro and Bayman 2011). However, to the best of our knowledge, the relationships between the endophytes have never been characterized in the stem end of the fruit.

In this study, we characterized the fungal and bacterial microbiota colonizing the mango fruit stem end and its dynamics during storage in resistant (red-peeled) and susceptible (green-peeled) mango fruit stored at different temperatures.

\section{MATERIALS AND METHODS}

Plant material and cold storage (CS). Mango (Mangifera indica L.) 'Shelly' fruit were harvested from two different canopy positions: the "red" colored fruit (more than 60\% of fruit peel is red) were harvested from the exterior position and the "green" colored fruit (less than $10 \%$ of fruit peel is red) from the interior position, in an orchard near the Sea of Galilee (Sivankalyani et al. 2016a). Uniform, unblemished fruit weighing about $340 \mathrm{~g}$ were washed with tap water and air-dried on the bench. Separate cardboard boxes, each containing 10 either red or green fruit, were used for the CS experiment. Five boxes for each peel color at each storage temperature $\left(5\right.$ or $\left.12^{\circ} \mathrm{C}\right)$ were stored for 3 weeks in the cold and then transferred to shelf-life (SL) storage at $20^{\circ} \mathrm{C}$. Total anthocyanin fluorescence was measured by Multiplex (Multiplex III, Force A, France) (Sivankalyani et al. 2016a).

SER and side decay of red and green mango fruit. Percentages of fruit with SER and side decay were evaluated for each box. Measurements were performed after 3 weeks in CS $\left(5\right.$ or $\left.12^{\circ} \mathrm{C}\right)$ and again after an additional 7 days of SL $\left(20^{\circ} \mathrm{C}\right)$. The rotten fruits were not removed. The experiments were repeated three times, in 2014, 2015, and 2016, with similar results. Presented results are from 2014.

Microscopic observations. Mango fruit with natural inoculation at two ripening stages (green-unripe and fully ripe) were stained with aniline blue (Hood and Shew 1996). Mango stem ends were infected with green fluorescent protein (GFP)-labeled Alternaria alternata (D. Ezra, unpublished data). Stem ends were manually cut into strips for microscopic observation. All fluorescent pictures were viewed with a laser-scanning confocal microscope (Olympus IX81, Center Valley, PA).

Tissue sampling. Only healthy mango fruit were sampled. The fruits were sterilized externally with $1 \%$ sodium hypochlorite solution for $2 \mathrm{~min}$ and then washed with sterile water for $1 \mathrm{~min}$ in order to remove epiphytic microorganisms. Stem ends from healthy-looking fruit were sampled $(10 \mathrm{~mm}$ long, half external to the fruit and the other half internal) using a sterile surgical blade. A total of 60 stem ends were collected over three sampling times (harvest, after CS, after SL). All samples were immediately frozen in liquid nitrogen and stored at $-80^{\circ} \mathrm{C}$ for later analysis.

DNA extraction. Stem-end tissue was freeze-dried (Christ alpha 1-2 freeze dryer, Osterode am Harz, Germany) for $5 \mathrm{~h}$ and ground using a mortar and pestle with liquid nitrogen. DNA was extracted following the CTAB protocol modified from Kumar et al. (2012). Modifications included incubation $\left(60^{\circ} \mathrm{C}, 10 \mathrm{~min}\right)$ in $10 \% \mathrm{CTAB}$ (wt/vol) and $5 \mathrm{M} \mathrm{NaCl}$ between chloroform/isoamyl purifications. The pellet was incubated with RNAse $(0.05 \mathrm{mg}$ per sample $)$ at $37^{\circ} \mathrm{C}$ for $30 \mathrm{~min}$ and an additional precipitation in ethanol (3 M sodium acetate, $\mathrm{pH}$ 5.2) was performed. DNA quality and quantity were evaluated and measured on a gel and by spectrophotometry (NanoDrop 1000 Spectrophotometer, Thermo Scientific, Wilmington, DE), respectively.

Amplification and sequencing. A targeted amplicon sequencing (TAS) approach was applied (Bybee et al. 2011; de Cárcer et al. 2011). Briefly, two PCR stages were used to generate amplicons for Illumina MiSeq sequencing. First, 28 PCR cycles were performed with genomic DNA and CS1 + CS2 primers containing 5' linker sequences. The PCR amplification was validated by agarose gel electrophoresis. An aliquot of the PCR yield was transferred to a second PCR with new primer targets containing linker sequences for an additional eight cycles before sequencing on the Illumina MiSeq platform. All PCRs contained 20 ng of DNA template, $1 \times$ KAPA HiFi Hot Start Ready Mix (KAPA Biosystems, Wilmington, MA) and 0.6 pmol of each primer. Each PCR was performed three times and the products were pooled. Amplicons were then submitted to DNA Services Facility (http://www.rrc.uic.edu/dnas) at the University of Illinois at Chicago (UIC) for a second PCR and Illumina MiSeq TAS similar to the method described in (Smith and Peay 2014).

For the bacterial microbiome, the V4 domain of bacterial $16 \mathrm{~S}$ rRNA genes was amplified in a nested PCR, in order to reduce plant organelle amplification. The first step was performed using primers 515F (modified) (5'-GTGCCAGCMGCCGCGGTAA-3') and 1062R (5'-CTCACRRCACGAGCTGAC-3'). Reaction conditions consisted of an initial $95^{\circ} \mathrm{C}$ for $3 \mathrm{~min}$ followed by 20 cycles of $98^{\circ} \mathrm{C}$ for $20 \mathrm{~s}, 58^{\circ} \mathrm{C}$ for $15 \mathrm{~s}, 72^{\circ} \mathrm{C}$ for $1 \mathrm{~min}$, and a final extension of $72^{\circ} \mathrm{C}$ for $5 \mathrm{~min}$. The second step was performed using 1:10 dilution of product from the previous step as the template, with primers containing "common sequences." The second nested PCR step was performed using primers: CS1_515F (5'-ACACTGACGACATGGT TCTACAGTGCCAGCMGCCGCGGTAA-3') and CS2_806R (5'TACGGTAGCAGAGACTTGGTCTGGACTACHVGGGTWTCTA AT- $\left.3^{\prime}\right)$; cycling conditions remained the same, with an annealing temperature of $52^{\circ} \mathrm{C}$ and 5 to 8 cycle until a visible band could be detected on gel with expected length of $291 \mathrm{bp}$.

For the fungal microbiome, fungal internal transcribed spacer (ITS) 1 loci were amplified with primers CS1_BITS (5'-ACACTGACGA CATGGTTCTACAACCTGCGGARGGATCA-3') and CS2_B58S3 (5'-TACGGTAGCAGAGACTTGGTCTGAGATCCRTTGYTRAA AGTT- $\left.3^{\prime}\right)$. Reaction conditions consisted of an initial $95^{\circ} \mathrm{C}$ for $3 \mathrm{~min}$ followed by 28 (or less) cycles of $98^{\circ} \mathrm{C}$ for $20 \mathrm{~s}, 56^{\circ} \mathrm{C}$ for $15 \mathrm{~s}, 72^{\circ} \mathrm{C}$ for $1 \mathrm{~min}$, and a final extension of $72^{\circ} \mathrm{C}$ for $5 \mathrm{~min}$ until a visible band could be detected on gel with expected length of 205 bp (based on Alternaria alternata sequence).

Data analysis and statistics. Raw Illumina FASTQ files were demultiplexed, quality-filtered, and analyzed using QIIME v 1.8 (Caporaso et al. 2010b). Forward and reverse reads were merged using PEAR (Zhang et al. 2014). The merged FASTQ files were imported to CLC for quality and length trimming. A Q20 quality trim was performed and anything $<50$ bp was discarded. Primers and PhiX contamination were removed from the samples. Chimera filtering was performed using the USEARCH algorithm with the GreenGenes 13_8 reference sequences (Edgar 2010; McDonald et al. 2012).

Following quality filtering, the bacterial $16 \mathrm{~S}$ generated 4,232,505 reads (252.4 nucleotides mean length) and the fungal ITS generated $1,937,853$ reads (188.8 nucleotides mean length). Sequence rarefaction curves, demonstrating per-sample sequence coverage, are shown in the Supplementary Figs. S1, S2, and S3.

Operational taxonomic units (OTUs) were assigned using QIIME's UCLUST (Caporaso et al. 2010b) with a threshold of $97 \%$ sequence similarity. Reference-based OTU picking was performed using a representative subset of the Greengenes bacterial 16S rRNA database (13_8 release) (DeSantis et al. 2006) or UNITE (12_11 release) (Abarenkov et al. 2010) as the fungal ITS database. Taxonomic annotations were assigned to each OTU using the representative sequence data, UCLUST and the reference database. Taxonomic and OTU abundance data were merged into a single OTU table and summaries of relative abundances of taxa were generated for the family level in the dataset. Bacterial 16S rRNA gene sequences were aligned using PyNAST (Caporaso et al. 2010a), fungal ITS 
sequences were aligned using MAFFT (Katoh and Standley 2013), and a phylogenic tree was generated from the filtered alignment using FastTree (Price et al. 2010). Any OTU that appeared less than 10 times in the ITS project and less than two times in the $16 \mathrm{~S}$ project was removed to avoid inclusion of erroneous reads, leading to inflated estimates of diversity. Alpha-diversity (within-sample species richness) and beta-diversity (between-sample community dissimilarity) estimates were calculated using QIIME weighted UniFrac distance (Lozupone and Knight 2005) between samples for bacterial 16S rRNA and fungal ITS reads. Principal coordinates were computed from the resulting distance matrices to compress dimensionality into $3 \mathrm{D}$ principal coordinate analysis (PCoA) plots using the Emperor tool (Vázquez-Baeza et al. 2013), thus enabling visualization of relationships between samples. To determine whether sample classifications (color, storage temperature, and storage time) contained differences in phylogenetic or family diversity, ANOSIM (Clarke 1993) and permutational ADONIS (Oksanen et al. 2007) with 999 permutations were used to test significant differences between sample groups based on weighted UniFrac distance matrices (Lozupone and Knight 2005). To determine taxonomic dissimilarity between samples (UniFrac), unweighted pair group method with arithmetic mean (UPGMA) trees were constructed in QIIME for both bacterial 16S and fungal ITS.

Comparing OTU frequencies across sample groups: a QIIME script was used to compare OTU frequencies in sample groups and to determine whether there are significant differences between the OTU abundance in the different sample groups. The differential frequency of each family among samples was detected with a Kruskall-Wallis test independently for the bacterial and fungal datasets. The test was applied for the family level using QIIME. In both cases, $P$ values were corrected by the Benjamini-Hochberg FDR procedure for multiple comparisons. A threshold of $P \leq 0.05$ was used to determine whether a family was differentially enriched in a given condition.

\section{RESULTS}

Colonization of fruit stem end by endophytic fungi. Preliminary experiments showed that all mango stems, which were sampled over 4 months from flowering until fruit harvest during three seasons, were colonized with the fungi Alternaria alternata, L. theobromae, C. gloeosporioides, and others (unpublished data 2014) but were asymptomatic.

To understand the location and growth patterns of endophytic fungal colonization inside the stem end, stems from freshly harvested unripe fruit and ripe fruit after storage were examined. Stem ends were stained with aniline blue and examined under a confocal microscope. In unripe fruit, fungal hyphae were limited and grew along the phloem cells (Fig. 1A). In ripe fruit however, when the fungi switched to necrotrophic colonization, the initiation of SER could be observed. Necrotrophic fungal colonization showed a substantially larger mass of hyphae that were highly branched and had breached the limits of the phloem cells and colonized the surrounding fruit parenchyma tissue (Fig. 1B). A similar pattern of colonization, i.e., of the phloem cells until fruit ripening and then a switch to branched colonization of the fruit parenchyma, was observed after infecting ripe and unripe fruits with GFP-labeled Alternaria alternata (Fig. 1C and D). In general, even though all fruit were endophytically colonized by fungal pathogens, external SER symptoms appeared only as the fruit began to ripen (Fig. 1E). Interestingly, not all of the ripened fruit developed SER, even when mycelia were observed inside the phloem.

SER and the microorganismal community in mango fruit stem ends. To study the SER and microbiome in mango stem ends, red and green mango fruits were harvested at a mature-unripe stage, and stored in cardboard boxes for 21 days under optimal $\left(12^{\circ} \mathrm{C}\right)$ or suboptimal $\left(5^{\circ} \mathrm{C}\right) \mathrm{CS}$, and for an additional 7 days at $20^{\circ} \mathrm{C}$ to mimic SL storage. Samples were taken for DNA isolation and fruit were evaluated for rot. Isolated DNA was amplified with fungal (ITS) and bacterial (16S) primers, deep sequenced and analyzed bioinformatically and statistically.

We characterized the taxonomic abundance of major fungal and bacterial families in mango stem ends. The four most abundant fungal families observed in the stem-end tissue: Pleosporaceae, Dothioraceae, Davidiellaceae, and Botryosphaeriaceae, are all recognized as mango SER pathogens (Johnson et al. 1991, 1992b), which occur endophytically in the stem tissue of mango trees. Other families included species that are considered secondary pathogens (Trichocomaceae), saprophytes (Sclerotiniaceae, Hypocreaceae), yeast-like organisms with a widespread habitat (Metschnikowiaceae, Sporidiobolaceae), and other plant pathogens (Quambalariaceae) (Table 1). To the best of our knowledge, no characterization of the bacterial microorganisms in fruit stem ends has ever been reported. Our results indicated that the most abundant bacterial families are the Chitinophagaceae, Enterobacteriaceae, Comamonadaceae, Bradyrhizobiaceae, Pseudomonadaceae, Staphylococcaceae, and Bacillaceae (Table 1), all of which are found in diverse environmental habitats such as water, soil, and plants.

Dynamics of the mango stem-end microbial community during storage. Samples were taken from six different fruits at three time points: harvest, after CS, and after SL. During storage and fruit ripening a significant increase in SER was observed (Fig. 2A). Simultaneously, a significant change was observed in the bacterial communities and fungal communities in both the stem ends of red and green mango fruit (Table 2). Hierarchical clustering showed that both the fungal and bacterial communities in the stem ends were arranged as possible clusters according to the time points with closer proximity between the samples of stem ends at the earlier time point and wider variance in the communities after SL (Fig. 3A and B).

PCoA of the fungal community showed that each group (harvest, $\mathrm{CS}$, and SL) clustered together. At harvest, most of the samples were clustered in the upper-right side of the graph, whereas after CS and SL storage, the samples could be seen on the left side of the graph (Fig. 3C). In the PCoA plot of the bacterial community, most of the samples collected at harvest were clustered in the upper-left side of the graph and with time, the species composition changed, as demonstrated by the shift to the right side of the graph (Fig. 3D). Interestingly, many changes in the microbiomes of fungi and bacteria were detected across time after harvest (Fig. 3E and F). For example, fungal taxa that seemed abundant at harvest, including Sporidiobolaceae and Metschnikowiaceae significantly reduced and almost disappeared after CS and were not detectable after SL (Table 3). The opposite effect was observed in the bacterial community, where Chitinophagaceae significantly shifted from almost undetectable at harvest to becoming the second most abundant taxon after SL (Fig. 3E and F; Table 3). Other major changes in the fungal microbiota included a significant increase in Botryosphaeriaceae (Lasiodiplodia and others) and an increase in Pleosporaceae (Alternaria) in the CS and SL samples (Fig. 3E; Table 3). The increase in Pleosporaceae and Botryosphaeriaceae pathogens was correlated with the increase in SER occurring after CS and more significantly, after SL (Fig. 2A).

Does storage temperature define stem-end microbial community? To determine the importance of storage temperature on the microbial dynamics of the SER microbiome, mango fruit were harvested and stored for 21 days at either optimal $\left(12^{\circ} \mathrm{C}\right)$ or suboptimal $\left(5^{\circ} \mathrm{C}\right)$ temperature. The fungal and bacterial community structures varied significantly between the two storage temperatures in the red 
fruit (Table 2), whereas only the bacterial community structure varied between the two temperatures in green fruit (Table 2). Further analysis was carried out on the red mango stored at 12 or $5^{\circ} \mathrm{C}$ for 21 days (CS). Both hierarchical cluster tree (Fig. 4A and B) and PCoA (Fig. 4C and D) showed a distinct separation between both the fungal and bacterial communities in stem ends of mango fruit stored at each temperature. The bacterial community showed a minor increase in Bradyrhizobiaceae and a major increase in Brevibacteriaceae at $12^{\circ} \mathrm{C}$. The fungal community was dominated by the family Dothioraceae (Dothiorella) in fruit that were stored at $5^{\circ} \mathrm{C}$ compared with $12^{\circ} \mathrm{C}$, whereas the Botryosphaeriaceae (Lasiodiplodia) and Pleosporaceae (Alternaria) prevailed in fruit that were stored at $12^{\circ} \mathrm{C}$ (Fig. $4 \mathrm{E}$ and F; Table 3). Interestingly, while the main pathogenic fungal families were more dominant in fruit stored at $12^{\circ} \mathrm{C}$, the percentage of SER was similar in fruit stored at both temperatures, and even slightly more SER was observed at $5^{\circ} \mathrm{C}$ after SL (Fig. 2B), suggesting that fungal community is probably not the only factor that determines the incidence of SER, as the family Trichocomaceaea, which includes well established saprophytes

TABLE 1

General taxonomic abundance of major fungal and bacterial families in mango stem ends

\begin{tabular}{lclc}
\hline Bacterial family & $\begin{array}{c}\text { Total } \\
\text { percent }\end{array}$ & Fungal family & $\begin{array}{c}\text { Total } \\
\text { percent }\end{array}$ \\
\hline Chitinophagaceae & 43.55 & Pleosporaceae & 40.15 \\
\hline Enterobacteriaceae & 19.57 & Dothioraceae & 16.67 \\
\hline Comamonadaceae & 5.74 & Davidiellaceae & 11.76 \\
\hline Bradyrhizobiaceae & 3.82 & Botryosphaeriaceae & 11.76 \\
\hline Pseudomonadaceae & 2.84 & Trichocomaceae & 8.24 \\
\hline Staphylococcaceae & 2.42 & Metschnikowiaceae & 5.26 \\
\hline Bacillaceae & 2.20 & Sporidiobolaceae & 3.68 \\
\hline Sphingomonadaceae & 2.04 & Hypocreaceae & 0.54 \\
\hline Micrococcaceae & 1.62 & Quambalariaceae & 0.29 \\
\hline Oxalobacteraceae & 1.22 & Sclerotiniaceae & 0.24 \\
\hline
\end{tabular}
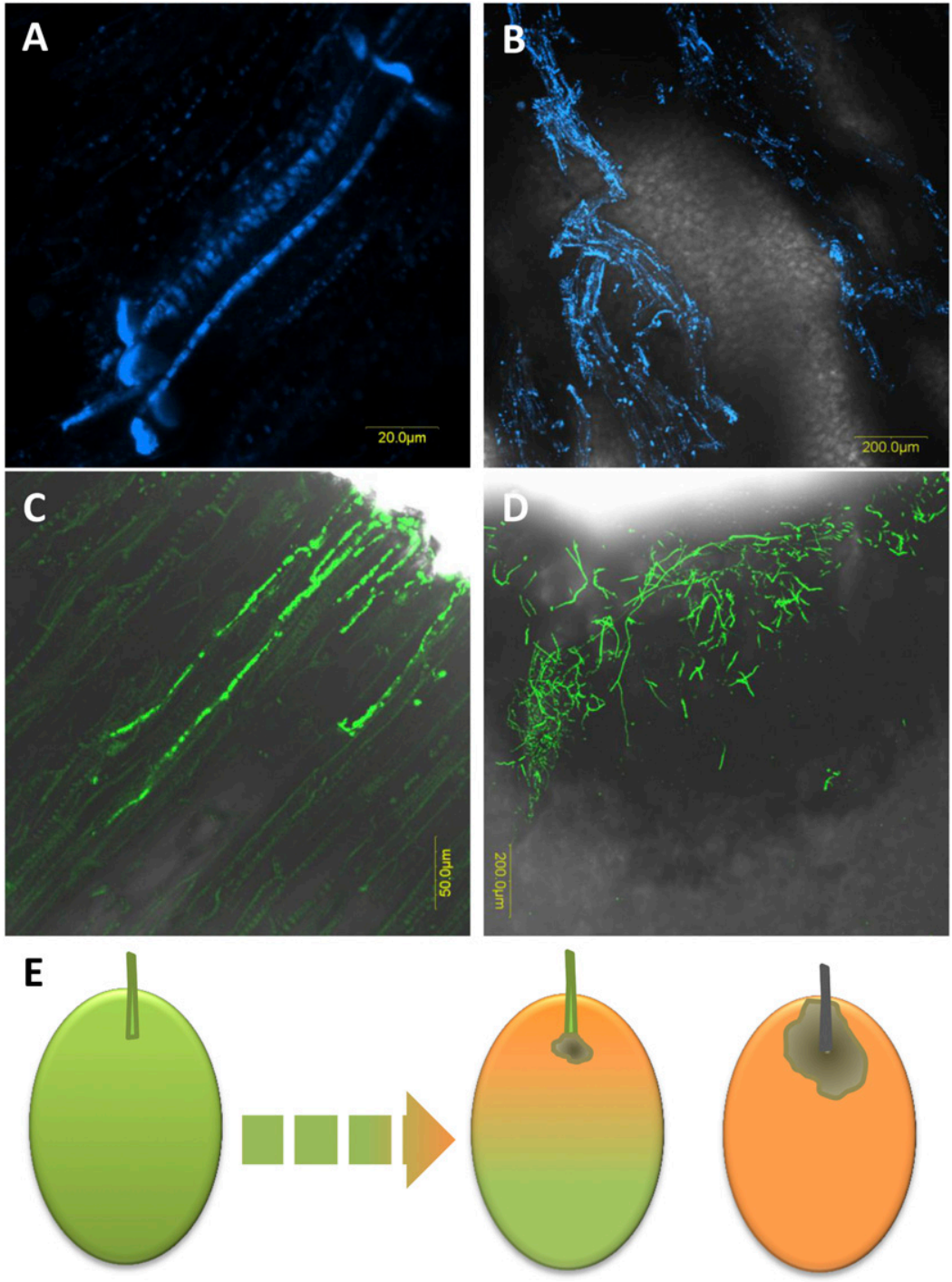

Fig. 1. Endophytic fungal colonization of stem end during fruit ripening. A and B, Confocal microscopic images of mango stem end stained with aniline blue. A, Fungal colonization of the phloem cells in the stem of freshly harvested unripe fruit. B, Initiation of natural stem-end rot (SER) in ripe mango fruit after storage. C and D, Confocal microscopic images showing fungal colonization of GFP-labeled Alternaria alternata inoculated on C, unripe ( 6 days postinoculation [dpi]) and D, ripe ( $3 \mathrm{dpi}$ ) stem ends. E, Scheme describing SER development in unripe (left), color-break (middle), and fully ripe (right) mango fruit. 
(Penicillium, Aspergillus) is significantly expanded in $5^{\circ} \mathrm{C}$ compared with $12^{\circ} \mathrm{C}$ (Table 3 ), suggesting increased rotten tissue in fruits stored in suboptimal temperature.

Peel color influences mango stem-end microbiota. Mango fruit that develop on the exterior of the tree canopy and are exposed to direct sunlight develop red-colored peel via activation of anthocyanin synthesis, and are more resistant to fungal development (Sivankalyani et al. 2016a). To determine the importance of fruit color on the dynamics of the microbiome, red and green mango fruit were harvested and stored at 5 or $12^{\circ} \mathrm{C}$. After harvest, a nonsignificant difference was observed between the composition of fungal and bacterial communities of the red and green mango fruit (Supplementary Fig. S4). Interestingly, after CS at 12 or $5^{\circ} \mathrm{C}$, the bacterial communities could be further differentiated between the red and green fruit (Table 2; Fig. 5).

PCoA and clustering (Fig. 5A to D) of red and green mango fruit stored at $12^{\circ} \mathrm{C}$ showed that the microbiome in the stem end of red mango differs from that in the green fruit. This effect was significant for bacteria and less pronounced for fungi (Table 2). Major taxonomic groups that were elevated in the fruit with green peels were known pathogen Pleosporaceae (Alternaria) and Trichocomaceae (common associates of decaying plant material) (Table 3), which were elevated in the fungal community. Chitinophagaceae was elevated in the bacterial community of the green mango (Fig. 5E and F; Table 3). Interestingly, green mango fruit had more SER than the red mango after CS and SL storage (Fig. 2A). This experiment was repeated in the following years (2015 to 2016) with similar results.

\section{DISCUSSION}

Mango SER is the second most devastating disease of mango fruit, after anthracnose caused by $C$. gloeosporioides (Prusky et al. 2009). It has been reported to be caused by various pathogens, which endophytically colonize the fruit pedicel and after the fruit ripens, cause SER (Prusky et al. 2009).

Stem-end fungal and bacterial communities. As the first manuscript to thoroughly investigate the fruit stem-end microbiome, it was important to first characterize the taxonomic abundance of fungal and bacterial families in mango stem ends. Endophytes, a diverse group of microorganisms that may complete their life cycle as endophytes, whereas other endophytes could become pathogenic or saprophytic fungi (Porras-Alfaro and Bayman 2011).
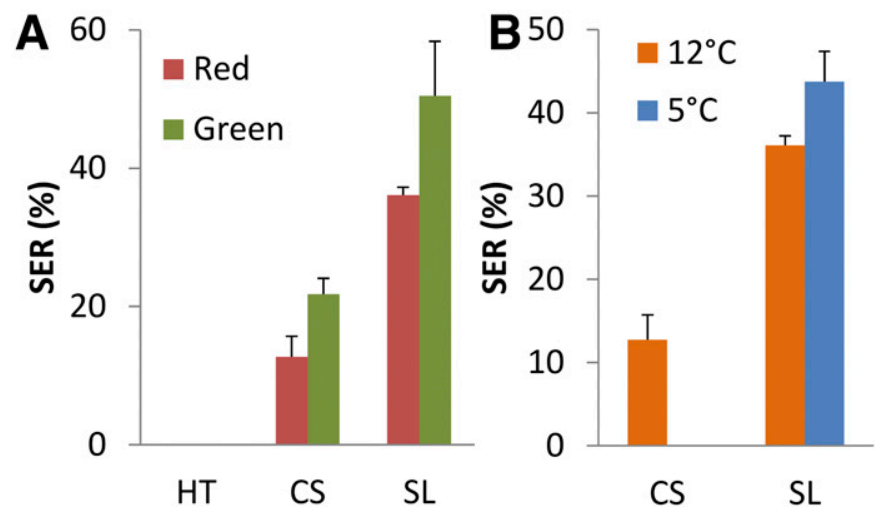

Fig. 2. Effect of mango fruit peel color, storage temperature, and storage time on stem-end rot (SER) development. A, Percentage of SER on red and green mango fruit after harvest, 3 weeks of cold storage (CS; $\left.12^{\circ} \mathrm{C}\right)$, and after further 7 days at shelf-life (SL) $\left(20^{\circ} \mathrm{C}\right)$. B, Percentage of SER on red mango fruit stored for 3 weeks in CS $\left(12\right.$ and $\left.5^{\circ} \mathrm{C}\right)$ and after an additional 7 days of $\mathrm{SL}\left(20^{\circ} \mathrm{C}\right)$.
The four most abundant fungal families found in mango stem ends in this study were Pleosporaceae, Dothioraceae, Davidiellaceae, and Botryosphaeriaceae, which are known mango pathogens. Those fungi occur endophytically in the stem tissue of mango trees prior to inflorescence emergence, and colonize the flowers during inflorescence (Johnson et al. 1991, 1992a). Alternaria alternata, a member of the family Pleosporaceae, is most abundant in semidry areas, and it is therefore the most devastating pathogen of mango fruit in Israel (Prusky et al. 2009). Dothiorella dominicana and Dothiorella mangifera (anamorph of Botryosphaeria dothidea) are members of the family Dothioraceae and are known to cause mango SER (Johnson et al. 1991, 1992a). The family Botryosphaeriaceae is composed of many pathogenic members, including Lasiodiplodia theobromae, Lasiodiplodia pseudotheobromae, Neofusicoccum parvum, Neofusicoccum mangiferum, Neoscytalidium novaehollandiae, Neoscytalidium dimidiatum, Pseudofusicoccum adansoniae, Pseudofusicoccum ardesiacum, Pseudofusicoccum kimberleyense, and Botryosphaeria dothidea, which commonly cause stem cankers, dieback, and SER of mango (Sakalidis et al. 2011). Cladosporium cladosporioides (a member of the Davidiellaceae) and Aspergillus niger (Trichocomaceae) are also known mango pathogens (Johnson et al. 1991, 1992a).

Other families, such as the Sclerotiniaceae, include necrotrophs, biotrophs, endophytes, and saprophytes (Andrew et al. 2012). Metschnikowiaceae and Sporidiobolaceae are yeast-like organisms with a broad habitat, and some of their species are known endophytes (Isaeva et al. 2010; Schaeffer et al. 2016). The Hypocreaceae are most often encountered as saprophytes on decaying wood but some species, such as Trichoderma, are considered biocontrol agents (Harman et al. 2004).

In this study, the most abundant bacterial family was the Chitinophagaceae, some species of which degrade chitin, while others hydrolyze cellulose (Rosenberg 2014). Enterobacteriaceae are widespread environmental organisms found in water, soil, plants, and human intestines. They include, alongside harmless symbionts, many of the more familiar human pathogens such as Salmonella and Escherichia coli. The Sphingomonadaceae are gram-negative organisms that are widespread in the environment, found in water, soil and as plant endophytes. Another interesting family is the Bacillaceae that includes Bacillus subtilis, which is a known biocontrol agent against postharvest fungal pathogens (Toure et al. 2004). Interestingly, a large number of bacterial families were found to live endophytically in the stem end of mango fruit. Those groups were previously

\begin{tabular}{|c|c|c|c|c|c|}
\hline \multicolumn{6}{|c|}{$\begin{array}{c}\text { TABLE } 2 \\
\text { Statistical analysis of category effects on microbial diversity } \\
\text { patterns conducted with Adonis and Permanova }\end{array}$} \\
\hline \multirow[b]{2}{*}{ Factor } & \multirow[b]{2}{*}{ Group } & \multicolumn{2}{|c|}{ Adonis } & \multicolumn{2}{|c|}{ Permanova } \\
\hline & & $R^{2}$ & $P$ & Pseudo- $F$ & $P$ \\
\hline \multicolumn{6}{|l|}{ Fungal ITS } \\
\hline Cold storage temp. & Red & 0.181 & 0.018 & 1.773 & 0.017 \\
\hline Color & $\begin{array}{r}\text { After cold } \\
\text { storage }\end{array}$ & 0.095 & 0.392 & 1.053 & 0.38 \\
\hline Storage time & Red & 0.169 & 0.019 & 1.527 & 0.014 \\
\hline \multicolumn{6}{|l|}{ Bacterial 16S } \\
\hline Cold storage temp. & Red & 0.143 & 0.028 & 1.237 & 0.01 \\
\hline Color & $\begin{array}{r}\text { After cold } \\
\text { storage }\end{array}$ & 0.097 & 0.042 & 1.074 & 0.041 \\
\hline Storage time & Red & 0.126 & 0.002 & 1.081 & 0.005 \\
\hline
\end{tabular}


found in diverse environmental habitats such as water, soil and plants (Goñi-Urriza et al. 2000; Neher 1999) (Table 1).

Fungal colonization of the mango fruit stem end. Endophytic fungi are known to colonize the plant phloem or xylem (Stone et al. 2004). Here we used aniline blue staining of mango stem end to show that both endophytic and pathogenic fungi colonize and grow along the phloem cells with almost no branching (Fig. 1). During this colonization, there are no visible symptoms. When the fruit ripens and its natural defense responses are compromised, the stemend pathogenic fungus is released from its endophytic lifestyle and enters a necrotrophic stage, causing SER (Prusky et al. 2013). At this early ripening stage, a small black lesion could be seen on the fruit stem end (Fig. 1), where the hyphae are released from the stem phloem and start to branch into the fruit parenchyma cells (Fig. 1) to cause SER.

Effects of fruit ripening and storage time on stem-end microbiome. Unripe mango fruits are resistant to SER (Fig. 2A) (Prusky et al. 2013). This resistance is compromised as the fruit ripens, and changes during storage. During fruit ripening, there are many physiological changes, including increased bioavailability of sugars and amino acids on the one hand, and a decrease in cell wall strength and plant-defense mechanisms on the other (Alkan and Fortes 2015). Since pathogenic

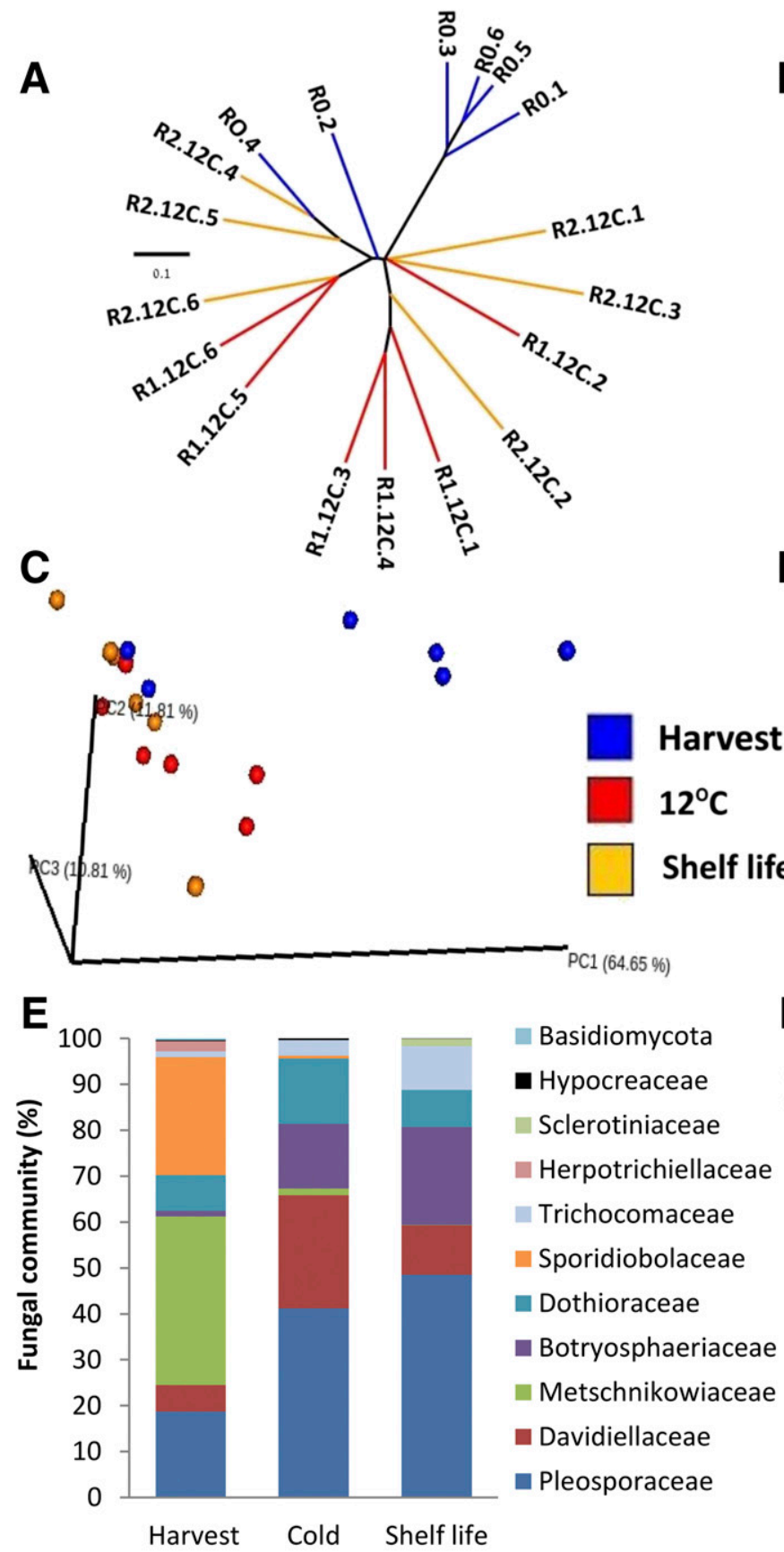

B

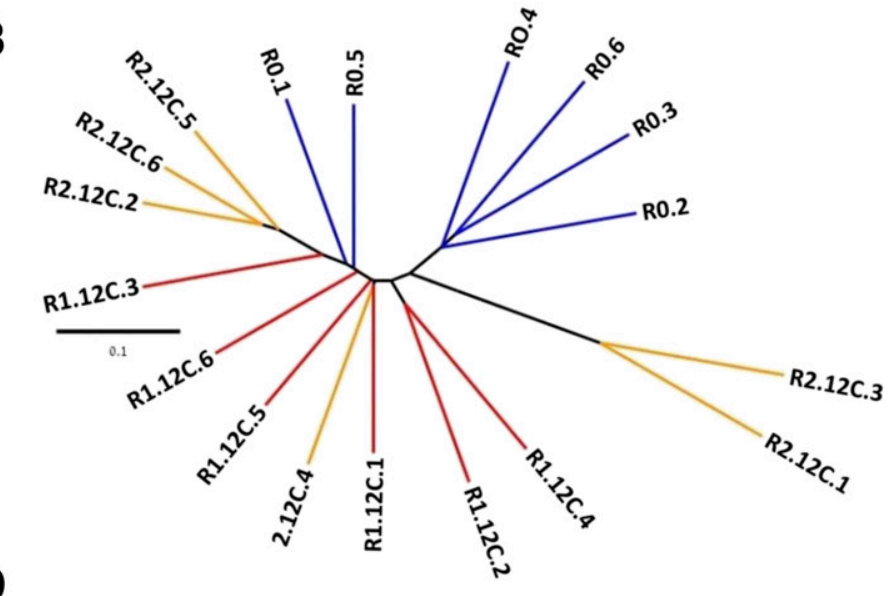

D

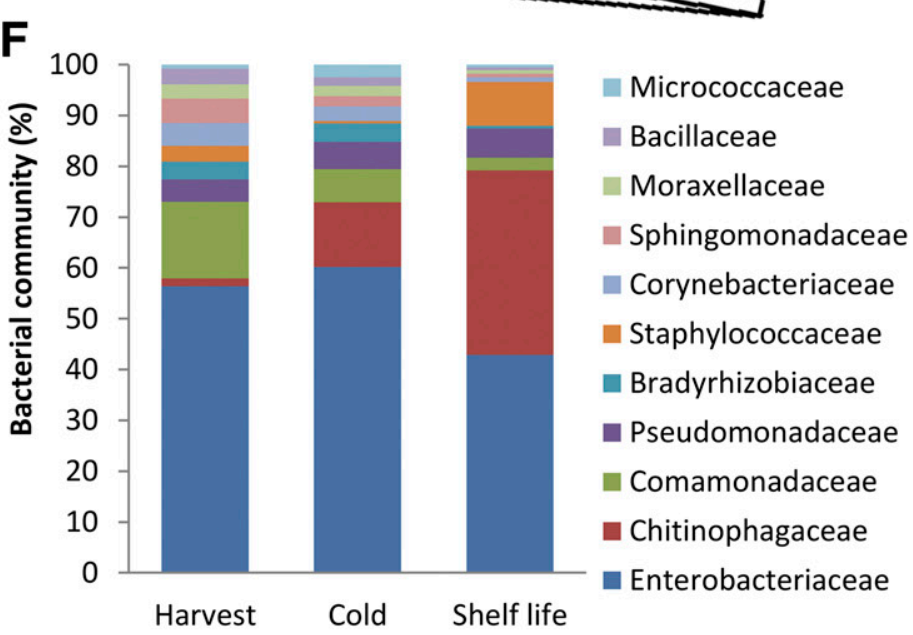

Fig. 3. Dynamics of fungal (left) and bacterial (right) communities during storage. A and B, Hierarchical cluster tree built using unweighted pair group method with arithmetic mean. Each name represents one sample; blue line, fruit after harvest; red line, fruit after storage at $12^{\circ} \mathrm{C}$; yellow line, fruit after additional shelf-life storage at $20^{\circ} \mathrm{C}$. C and D, Hierarchical cluster UniFrac distance PCoA of fungal (C) and bacterial (D) communities. E and F, Stacked column charts representing summarized taxonomic communities (family level) of fungi (E) and bacteria (F). 
fungi are present in the stem end in an endophytic state before fruit ripening (Johnson et al. 1991, 1992a), it is reasonable to assume that the fruit's resistance is one of the main causes for the fungi's inability to switch to necrotrophy. During fruit ripening, the fruit become susceptive and significant physiological shifts occurs, such as cell wall remodeling, soluble sugar accumulation, decrease in the amount of phytoanticipins and phytoalexins (5-pentadecyl-resorcinol), decline of inducible host defense responses, cuticle biosynthesis and changes in the ambient host pH (Alkan and Fortes 2015). The physiological changes that occur in the fruit during ripening modify the microorganism's environment, probably facilitating fungal growth and colonization. Indeed, during storage, the fruit ripens and a significant change occurs in both the fungal and bacterial communities (Table 2; Supplementary Fig. S5). Specifically, the fungal Sporidiobolaceae members decreased (Fig. 3E) some of which are known as biocontrol agents for postharvest diseases (Vero et al. 2013). On the other hand, members of the Pleosporaceae and Davidiellaceae increased significantly in the community (Fig. 3E); these families contain known pathogens, such as Alternaria and Cladosporium, respectively. Another family that expanded significantly from harvest to SL was Trichocomaceae, which may be used as an indicator of increased decay process. Thus, during storage and fruit ripening, the microbial community changes, and SERs increase dramatically (Fig. 2A; Table 3). More fungi appear in the stem end and this increase is correlated with a significant increase in the bacterial family Chitinophagaceae (Fig. 3F), which can degrade the chitin making up the fungal cell wall (Rosenberg 2014).

Effects of temperature on stem-end microbiome. The effects of temperature on endophytes are poorly characterized (Stone et al. 2004). However, it is well known that each fungus has an optimal temperature (frequently between 23 and $33^{\circ} \mathrm{C}$ ) and a restrictive temperature (frequently between 3 and $12^{\circ} \mathrm{C}$ ) that can influence sporulation, growth, and pathogenicity (Ayerst 1969). Similarly, each bacterial species has its optimal temperature (frequently between 30 and $40^{\circ} \mathrm{C}$ ) and restrictive temperature, while some species can live under extreme conditions (Lowe et al. 1993). Indeed, storing mango fruit at 12 or $5^{\circ} \mathrm{C}$ had a significant effect on both the bacterial and fungal communities (Table 2; Fig. 4; Supplementary Figs. S6 and S7). For example, several of the main pathogenic fungi, such as members of the families Pleosporaceae and Botryosphaeriaceae, were present in higher proportions in the community at the optimal storage temperature of $12^{\circ} \mathrm{C}$ (Fig. 4E).

Therefore, based on the microbiome, we could expect that more SER will be observed when storing fruit at $12^{\circ} \mathrm{C}$, which was indeed the case here, where the fruit started to ripen and a few incidences of SER could be seen (Fig. 2B, after CS). However, after additional SL storage, similar amounts of SER were detected in fruit stored at $5^{\circ} \mathrm{C}$, although less pathogenic fungi were seen in those fruit. Thus, it seems that in the case of storage temperature, the microbiome changes had less of an effect than the fruit's susceptibility to SER incidence.

It is worth mentioning that Trichocomaceae is expanding significantly in $5^{\circ} \mathrm{C}$ stored fruit (Table 3 ). Thus, in all the susceptive conditions in our experiments (green compared with red; after CS and SL compared with harvested fruits; $5^{\circ} \mathrm{C}$ compared with $12^{\circ} \mathrm{C}$ ) Trichocomaceae, which is a family usually identified with increased rotting plant material, was expanded and might be considered as a marker for SER prior to symptom appearance.

The optimal storage temperature for mango fruit is $12^{\circ} \mathrm{C}$; storage at $5^{\circ} \mathrm{C}$ leads to compromised defenses and chilling injuries (Sivankalyani et al. 2016b). Most of the chilling injuries consist of discolored lenticels, which accumulate dead cells. The accumulation of dead cells opens

TABLE 3

Differences in frequencies (\%) of fungal and bacterial families across the conditions in the current study

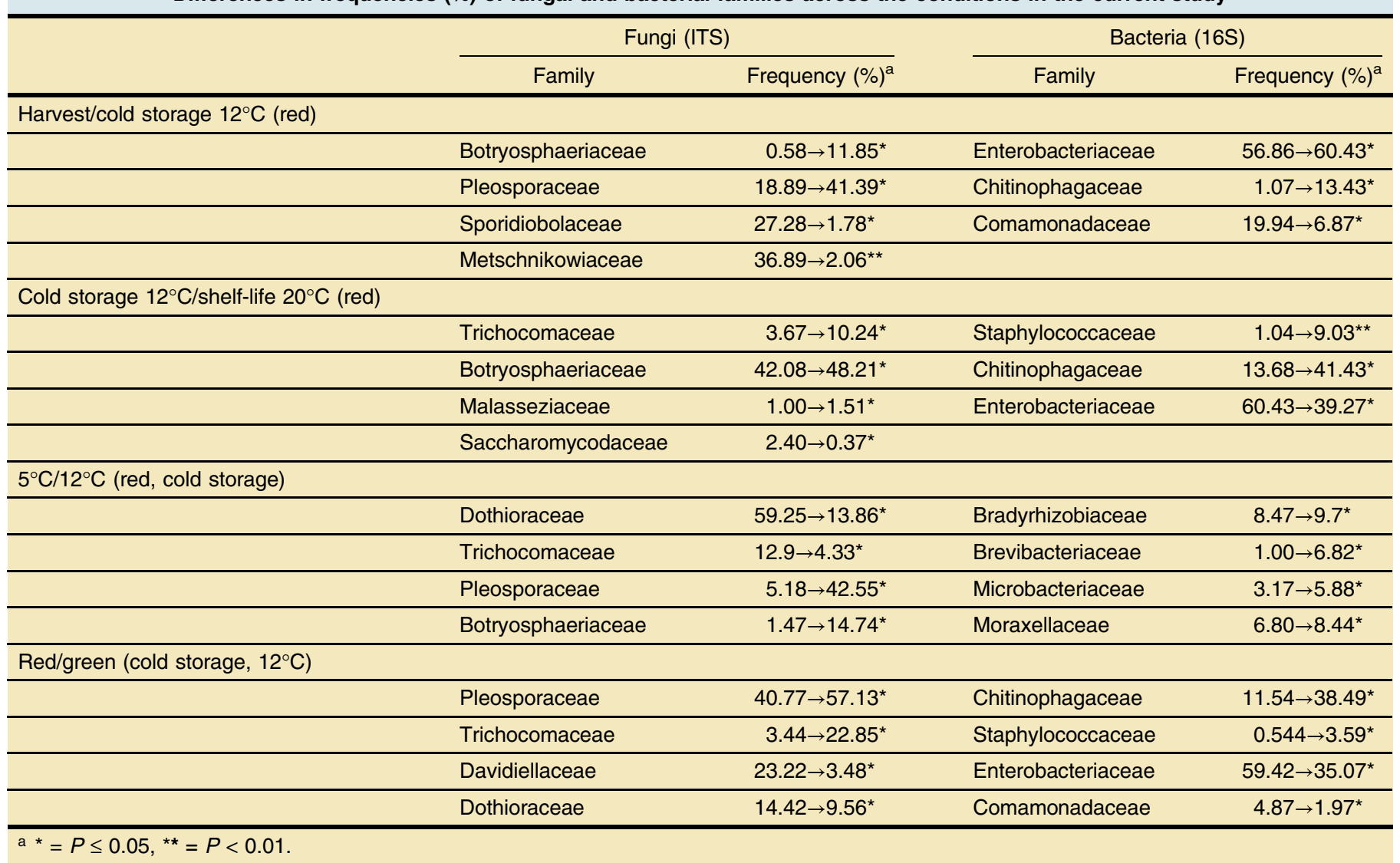


pores in the fruit cuticle that are strongly correlated with the later increase in side decay (Sivankalyani et al. 2016b).

Indeed, after SL storage, all of the fruit were ripe and those that were stored at the suboptimal temperature $\left(5^{\circ} \mathrm{C}\right)$ had a compromised defense response and developed SER more rapidly (Fig. 2B). This shows that ripening progress, fruit defense mechanisms and the microbial communities may act in opposing directions during storage at different temperatures, and in the current scenario, fruit susceptibility seems to have the major effect on SER outcome.
Anthocyanin and stem-end microbiome. Red mango fruit, which were exposed to sunlight in the orchard and contained higher amounts of anthocyanin, are more resistant to chilling injury and C. gloeosporioides inoculation on the peel (Sivankalyani et al. 2016a). Similarly, in our experiment, red mango fruit were more resistant to SER than green mango fruit (Fig. 2A).

We assume that some defense pathways, such as the phenylpropanoid pathway, were activated in the red fruit that was exposed to sunlight and accumulated anthocyanin in comparison with the green fruit (Supplementary Fig. S8), leading to induced resistance to
A
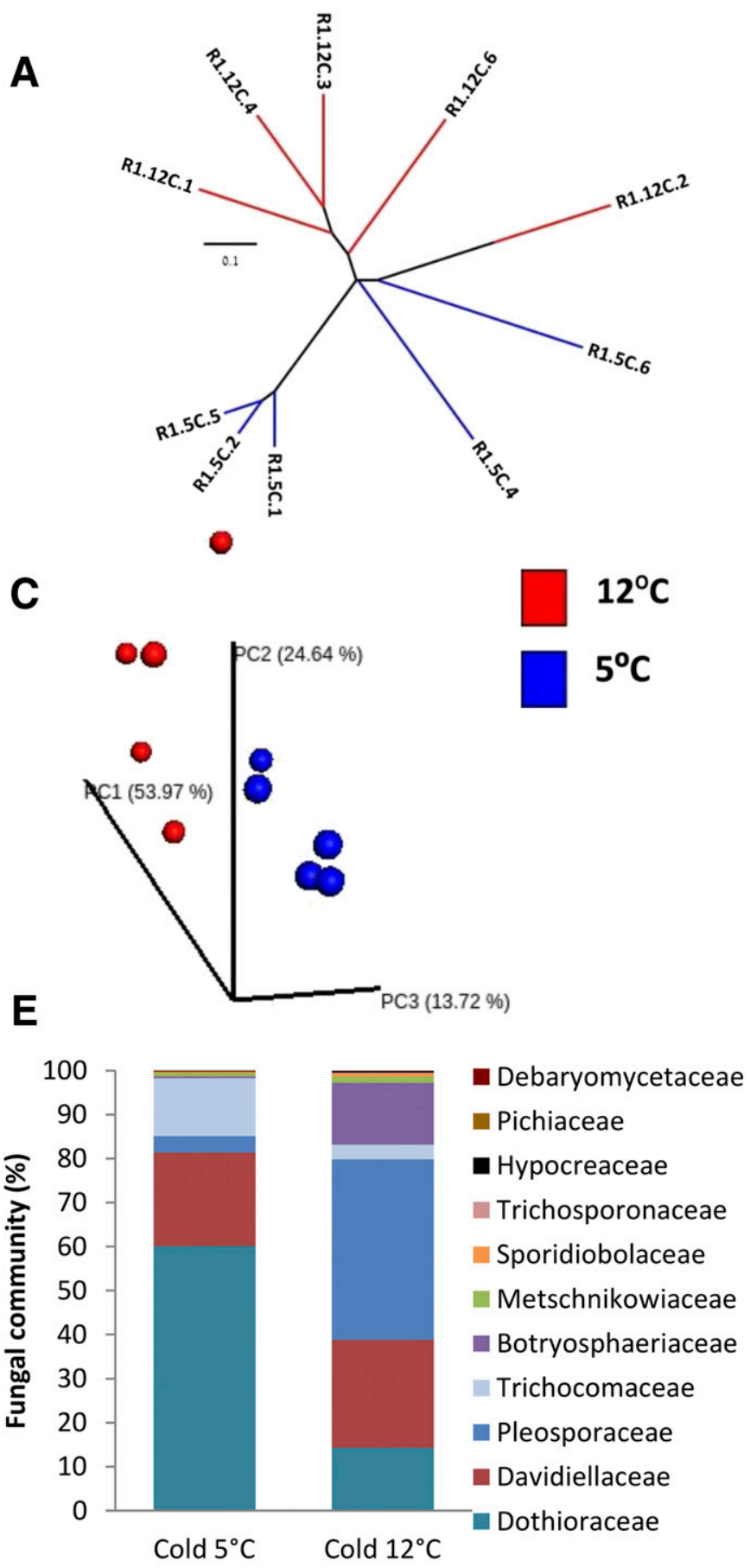

C

$12^{\circ} \mathrm{C}$

$5^{\circ} \mathrm{C}$

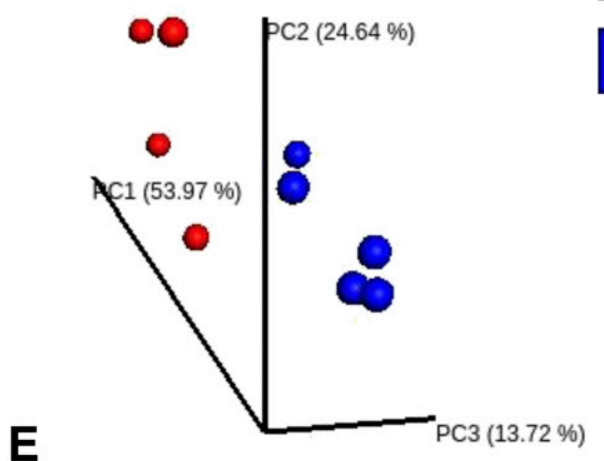

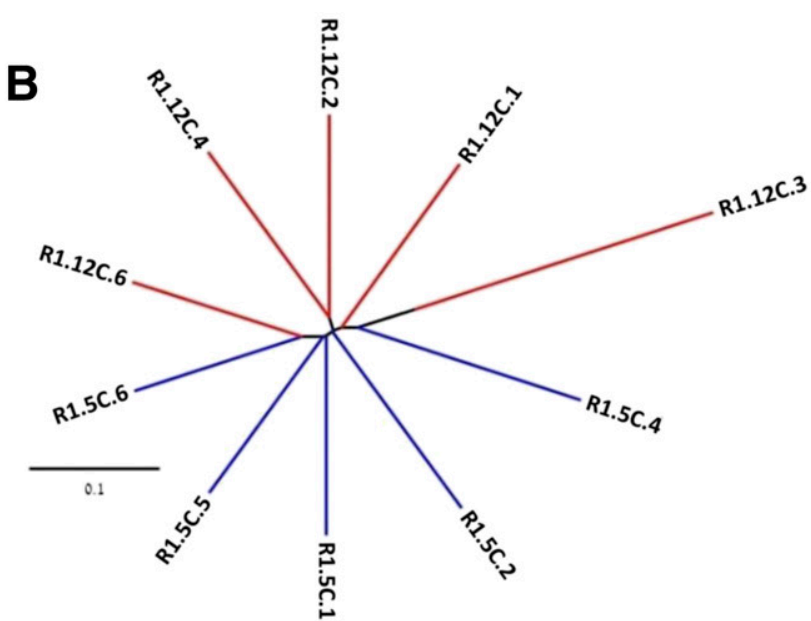

D

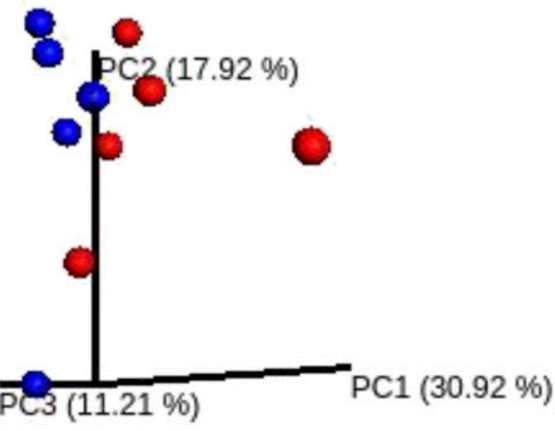

$\mathbf{F}$

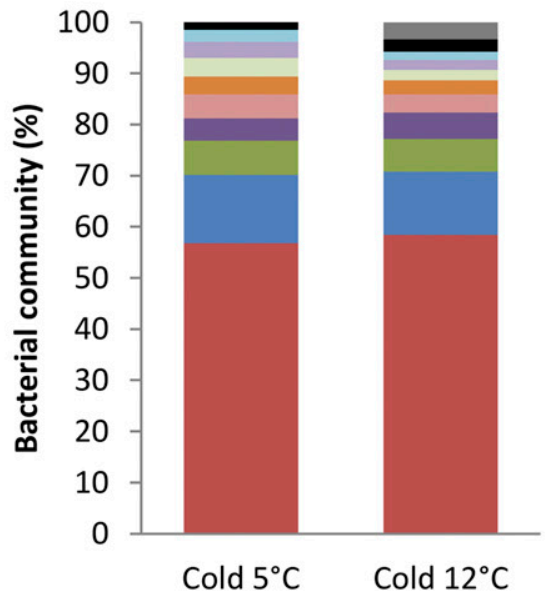

Brevibacteriaceae

Moraxellaceae

Oxalobacteraceae

Micrococcaceae

Sphingomonadaceae

Bacillaceae

- Pseudomonadaceae

Bradyrhizobiaceae

- Comamonadaceae

- Enterobacteriaceae

- Chitinophagaceae

Fig. 4. Dynamics of fungal (left) and bacterial (right) communities in response to storage temperature. A and B, Hierarchical cluster tree was built using unweighted pair group method with arithmetic mean. Each name represents one sample; red line, fruit after storage at $12^{\circ} \mathrm{C}$; blue line, fruit after storage at $5^{\circ}$ C. C and D, Bray-Curtis and weighted UniFrac distance PCoA of fungal (C) and bacterial (D) communities. E and F, Stacked column charts representing summarized taxonomic communities (family level) of fungi $(\mathbf{E})$ and bacteria $(\mathbf{F})$. 
pathogens. Indeed, accumulation of anthocyanin has been correlated to increased resistance to postharvest pathogens such as Botrytis (Jeandet et al. 2015). This induced resistance in red fruit probably led to a reduction in the population of some families of pathogenic fungi such as Pleosporaceae (Alternaria alternata) and Trichocomaceae (Aspergillus niger) (Fig. 5E). In turn, this probably led to increased fungal colonization in green fruit (Fig. 2A), which led to an increase in the bacterial family Chitinophagaceae (Fig. 5F) whose members degrade the chitin in the fungal cell wall (Rosenberg 2014), even before SER developed.

Microbiome community dynamics. It is well established that various treatments and conditions can affect bacterial community composition in soils (Cayuela et al. 2014). Similarly, the present research shows that exposure to high light in the orchard leads to red color accumulation in mango fruit peel (Sivankalyani et al. 2016a), which affects the postharvest fungal and bacterial community in the stem end (Fig. 5). In addition, postharvest conditions such as storage temperature and duration have a significant effect on both fungal and bacterial communities (Figs. 3 and 4).

A diverse community is correlated to a balanced and healthy microbiota that is more resistant to diseases. For example, highly diverse endogenous intestinal bacterial communities are correlated to human health (Eckburg et al. 2005). In an analogous manner, a notable result in all experiments described in this research was that "healthier" stem ends (with a lower incidence of SER) have a more diverse microbial community. This included fruit stored at higher
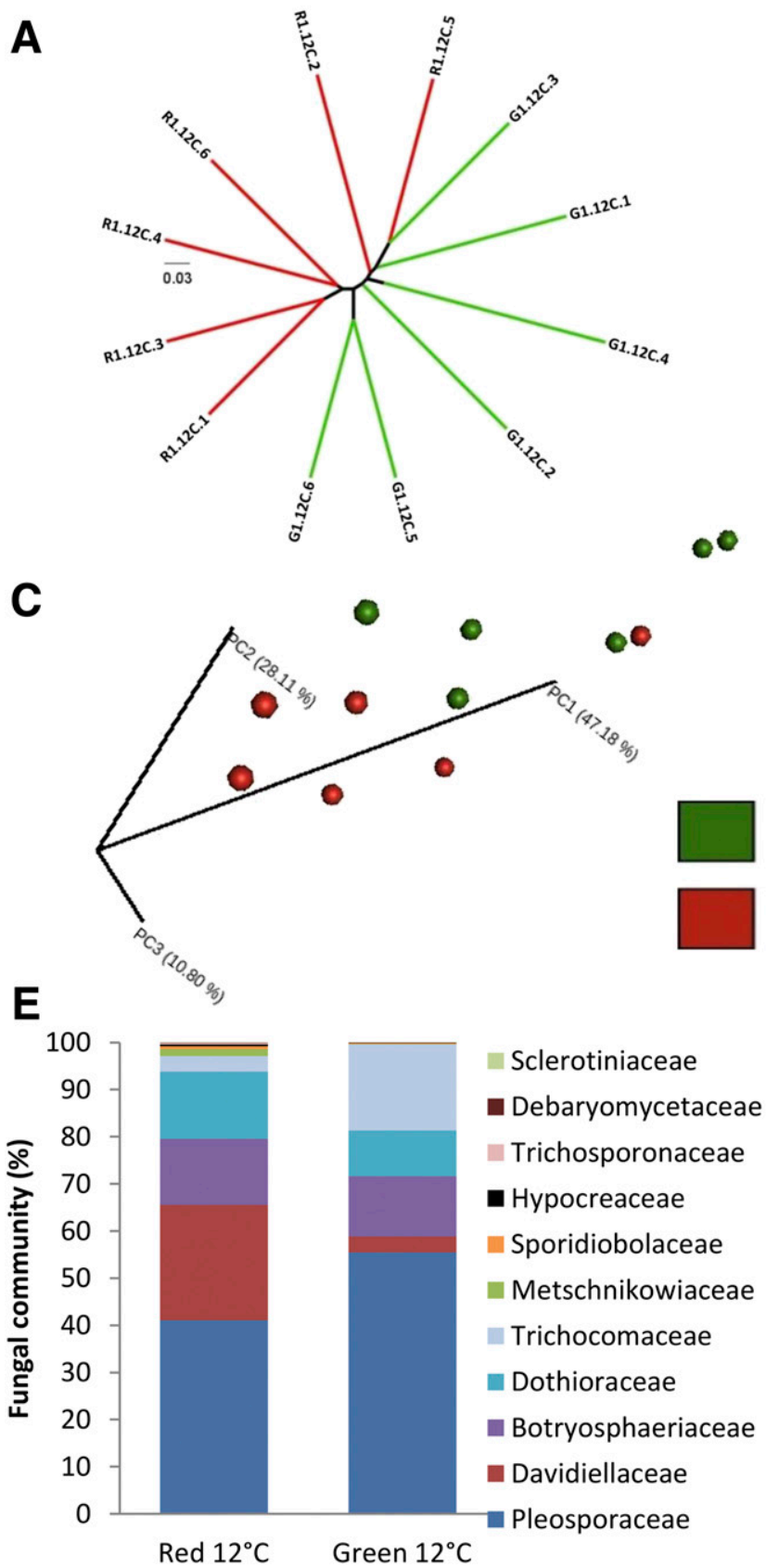

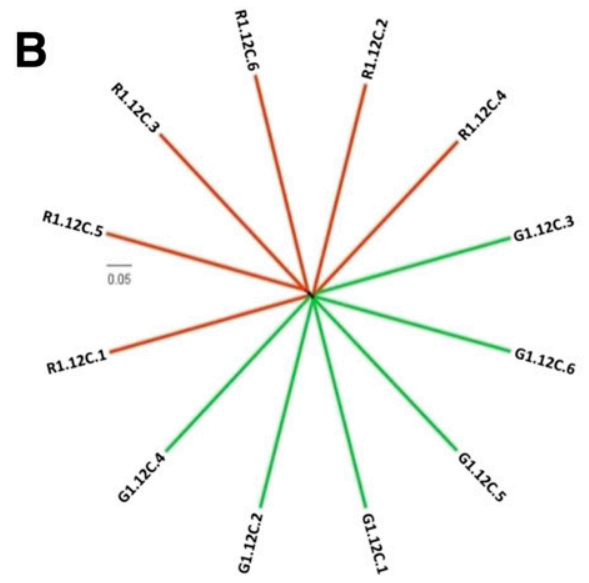

$\cdot 0$
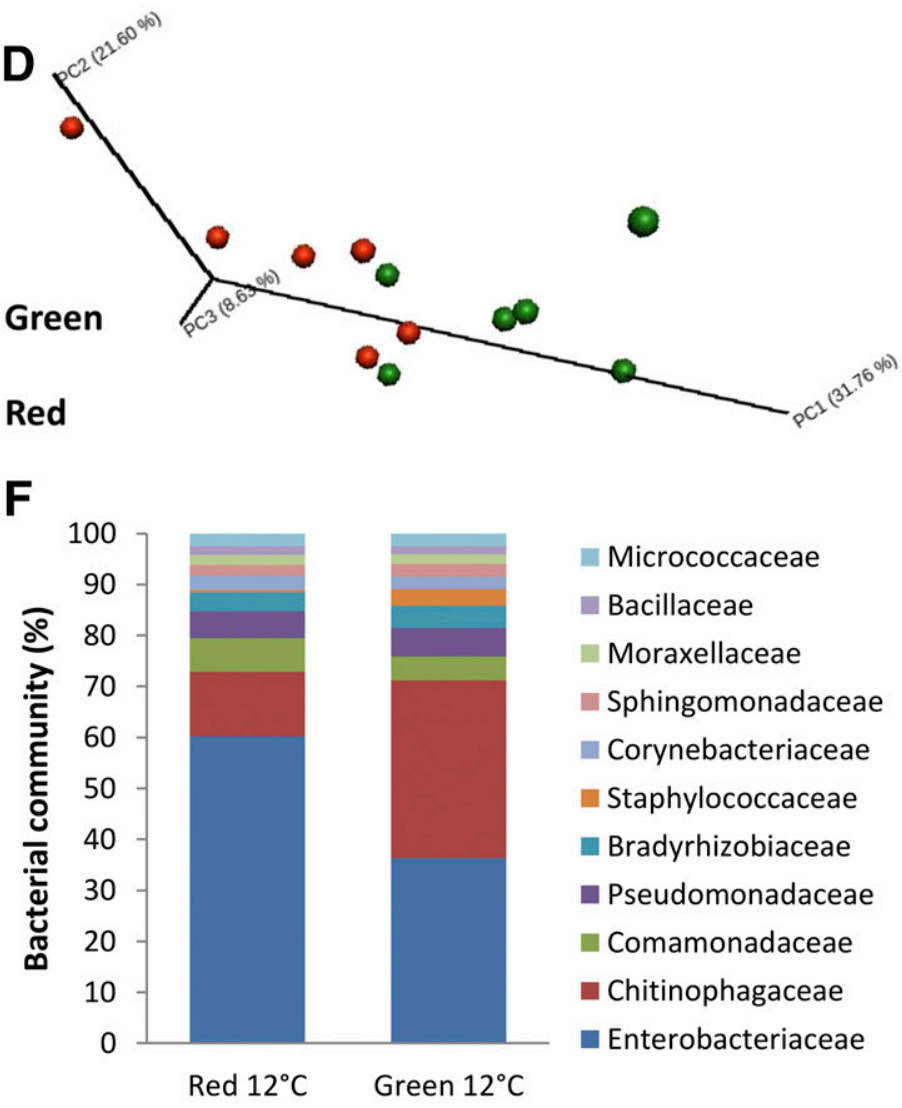

Fig. 5. Dynamics of fungal (left) and bacterial (right) communities due to peel color. A and B, Hierarchical cluster tree built using unweighted pair group method with arithmetic mean. Each name represents one sample; red line, red fruit; green line, green fruit after storage at $12^{\circ} \mathrm{C}$. C and $\mathbf{D}, \mathrm{Bray}-\mathrm{Curtis}$ and Weighted UniFrac distance PCoA of fungal (C) and bacterial (D) communities. E and F, Stacked column charts representing summarized taxonomic communities (family level) of fungi (E) and bacteria (F). 
temperature (Fig. 4), freshly harvested fruit (Fig. 3) and red fruit (Fig. 5). Thus, as in mammalians (Keesing et al. 2010), reduction in microbial diversity caused an expansion dominance of one or several fungal families, usually one of the major pathogens that cause postharvest rots in mango, such as Pleosporaceae and Botryosphaeriaceae, which was correlated to an increase in SER incidence.

The relationships between bacterial and fungal communities in the mango fruit are not yet clear and should be further investigated. One known bacterial biocontrol agent (Bacillus) was found in mango stem ends and others might follow. There are no known SER diseases caused by bacteria in mango fruits. However, bacteria can cause disease in mango trees. For example, bacterial black spot is caused by Pseudomonas syringae, and Xanthomonas campestris causes bacterial blotch of mango fruits (Ploetz 2003). Both Pseudomonas sp. and Xanthomonas sp. were identified in the stem-end microbiome in the current study, but no bacterial disease was observed in the fruit or in the orchard. Thus, many questions about the "balance of power" inside the mango fruit stem end remain to be studied.

Conclusions. This is the first manuscript to characterize the bacterial and fungal communities and their dynamics in the stem end of fruit. Our data show that different conditions significantly affect both communities and thus affect the incidence of SER. In several cases, increases in the pathogenic fungal families Pleosporaceae and Botryosphaeriaceae were correlated with an increase in SER. The increases in fungal abundance and SER were correlated with an increase in the chitin-degrading Chitinophagaceae bacteria. Finally, we show that SER significantly increases in green-peel versus red-peel mango fruit and during storage and fruit ripening.

\section{ACKNOWLEDGMENTS}

We thank D. Ezra for GFP-labeled Alternaria alternata. This manuscript is contribution number 772/17 from the Agricultural Research Organization, the Volcani Center, Israel. This research was supported by the Chief Scientist of the Israeli Ministry of Agriculture (grant 430056316).

\section{LITERATURE CITED}

Abarenkov, K., Henrik Nilsson, R., Larsson, K. H., Alexander, I. J., Eberhardt, U., Erland, S., Høiland, K., Kjøller, R., Larsson, E., and Pennanen, T. 2010. The UNITE database for molecular identification of fungi-Recent updates and future perspectives. New Phytol. 186:281-285.

Alkan, N., and Fortes, A. M. 2015. Insights into molecular and metabolic events associated with fruit response to post-harvest fungal pathogens. Front. Plant Sci. 6:889.

Andrew, M., Barua, R., Short, S. M., and Kohn, L. M. 2012. Evidence for a common toolbox based on necrotrophy in a fungal lineage spanning necrotrophs, biotrophs, endophytes, host generalists and specialists. PLoS One 7:e29943.

Ayerst, G. 1969. The effects of moisture and temperature on growth and spore germination in some fungi. J. Stored Prod. Res. 5:127-141.

Bybee, S. M., Bracken-Grissom, H., Haynes, B. D., Hermansen, R. A., Byers, R. L., Clement, M. J., Udall, J. A., Wilcox, E. R., and Crandall, K. A. 2011. Targeted amplicon sequencing (TAS): A scalable next-gen approach to multilocus, multitaxa phylogenetics. Genome Biol. Evol. 3:1312-1323.

Caporaso, J. G., Bittinger, K., Bushman, F. D., DeSantis, T. Z., Andersen, G. L., and Knight, R. 2010a. PyNAST: A flexible tool for aligning sequences to a template alignment. Bioinformatics 26:266-267.

Caporaso, J. G., Kuczynski, J., Stombaugh, J., Bittinger, K., Bushman, F. D., Costello, E. K., Fierer, N., Pena, A. G., Goodrich, J. K., and Gordon, J. I. 2010b. QIIME allows analysis of high-throughput community sequencing data. Nat. Methods 7:335-336.

Cayuela, M., Van Zwieten, L., Singh, B., Jeffery, S., Roig, A., and SánchezMonedero, M. 2014. Biochar's role in mitigating soil nitrous oxide emissions: A review and meta-analysis. Agric. Ecosyst. Environ. 191:5-16.

Clarke, K. R. 1993. Non-parametric multivariate analyses of changes in community structure. Aust. J. Ecol. 18:117-143. de Cárcer, D. A., Denman, S. E., McSweeney, C., and Morrison, M. 2011 Strategy for modular tagged high-throughput amplicon sequencing. Appl. Environ. Microbiol. 77:6310-6312.

DeSantis, T. Z., Hugenholtz, P., Larsen, N., Rojas, M., Brodie, E. L., Keller, K., Huber, T., Dalevi, D., Hu, P., and Andersen, G. L. 2006. Greengenes, a chimera-checked 16S rRNA gene database and workbench compatible with ARB. Appl. Environ. Microbiol. 72:5069-5072.

Eckburg, P. B., Bik, E. M., Bernstein, C. N., Purdom, E., Dethlefsen, L., Sargent, M., Gill, S. R., Nelson, K. E., and Relman, D. A. 2005. Diversity of the human intestinal microbial flora. Science 308:1635-1638.

Edgar, R. C. 2010. Search and clustering orders of magnitude faster than BLAST. Bioinformatics 26:2460-2461.

Goñi-Urriza, M., Capdepuy, M., Arpin, C., Raymond, N., Caumette, P., and Quentin, C. 2000. Impact of an urban effluent on antibiotic resistance of riverine Enterobacteriaceae and Aeromonas spp. Appl. Environ. Microbiol. 66:125-132.

Harman, G. E., Howell, C. R., Viterbo, A., Chet, I., and Lorito, M. 2004. Trichoderma species-Opportunistic, avirulent plant symbionts. Nat. Rev. Microbiol. 2:43-56.

Henningsson, S., Hyde, K., Smith, A., and Campbell, M. 2004. The value of resource efficiency in the food industry: A waste minimization project in East Anglia, UK. J. Clean. Prod. 12:505-512.

Hood, M., and Shew, H. 1996. Applications of $\mathrm{KOH}$-aniline blue fluorescence in the study of plant-fungal interactions. Phytopathology 86:704-708.

Isaeva, O., Glushakova, A., Garbuz, S., Kachalkin, A., and Chernov, I. Y. 2010. Endophytic yeast fungi in plant storage tissues. Biol. Bull. 37:26-34.

Jeandet, P., Sbaghi, M., Bessis, R., and Meunier, P. 2015. The potential relationship of stilbene (resveratrol) synthesis to anthocyanin content in grape berry skins. VITIS-J. Grapevine Res. 34:91.

Johnson, G. I., Mead, A. J., Cooke, A. W., and Dean, J. R. 1991. Mango stem end rot pathogens-Infection levels between flowering and harvest. Ann. Appl. Biol. 119:465-473.

Johnson, G. I., Mead, A. J., Cooke, A. W., and Dean, J. R. 1992a. Mango stem end rot pathogens-Fruit infection by endophytic colonization of the inflorescence and pedicel. Ann. Appl. Biol. 120:225-234.

Johnson, G. I., Mead, A. J., Cooke, A. W., and Dean, J. R. 1992b. Mango stem end rot pathogens-Fruit infection by endophytic colonization of the inflorescence and pedicel. Ann. Appl. Biol. 120:225-234.

Katoh, K., and Standley, D. M. 2013. MAFFT multiple sequence alignment software version 7: Improvements in performance and usability. Mol. Biol. Evol. 30:772-780.

Keesing, F., Belden, L. K., Daszak, P., Dobson, A., Harvell, C. D., Holt, R. D., Hudson, P., Jolles, A., Jones, K. E., Mitchell, C. E., Myers, S. S., Bogich, T., and Ostfeld, R. S. 2010. Impacts of biodiversity on the emergence and transmission of infectious diseases. Nature 468:647-652.

Kumar, S., Muthukumar, M., Kumar, R., and Bajpai, A. 2012. High quality genomic DNA extraction protocol from Litchi (Litchi chinensis Sonn). Plant Arch. 12:1109-1113.

Lowe, S. E., Jain, M. K., and Zeikus, J. G. 1993. Biology, ecology, and biotechnological applications of anaerobic bacteria adapted to environmental stresses in temperature, $\mathrm{pH}$, salinity, or substrates. Microbiol. Rev. 57:451-509.

Lozupone, C., and Knight, R. 2005. UniFrac: A new phylogenetic method for comparing microbial communities. Appl. Environ. Microbiol. 71:8228-8235.

McDonald, D., Price, M. N., Goodrich, J., Nawrocki, E. P., DeSantis, T. Z., Probst, A., Andersen, G. L., Knight, R., and Hugenholtz, P. 2012. An improved Greengenes taxonomy with explicit ranks for ecological and evolutionary analyses of bacteria and archaea. ISME J. 6:610-618.

Neher, D. 1999. Soil community composition and ecosystem processes: comparing agricultural ecosystems with natural ecosystems. Agrofor. Syst. 45:159-185.

Oksanen, J., Kindt, R., Legendre, P., O'Hara, B., Stevens, M. H. H., Oksanen, M. J., and Suggests, M. A. S. S. 2007. The vegan package. Community Ecology Package 10:631-637.

Ploetz, R. 2003. Diseases of mango. Pages 327-364 in: Diseases of Tropical Fruit Crops. CAB International, Wallingford, U.K.

Porras-Alfaro, A., and Bayman, P. 2011. Hidden fungi, emergent properties: Endophytes and microbiomes. Annu. Rev. Phytopathol. 49:291.

Price, M. N., Dehal, P. S., and Arkin, A. P. 2010. FastTree 2-Approximately maximum-likelihood trees for large alignments. PLoS One 5:e9490.

Prusky, D., Kobiler, I., Miyara, I., and Alkan, N. 2009. Fruit diseases. Pages 210-231 in: The mango, botany, production and uses. R. Litz, ed. CABI International, Wallingford, U.K.

Prusky, D., Alkan, N., Mengiste, T., and Fluhr, R. 2013. Quiescent and necrotrophic lifestyle choice during postharvest disease development. Annu. Rev. Phytopathol. 51:155-176. 
Rosenberg, E. 2014. The family Chitinophagaceae. Pages 493-495 in: The Prokaryotes. Springer-Verlag, Berlin, Germany.

Sakalidis, M. L., Ray, J. D., Lanoiselet, V., Hardy, G. E. S., and Burgess, T. I. 2011. Pathogenic Botryosphaeriaceae associated with Mangifera indica in the Kimberley region of Western Australia. Eur. J. Plant Pathol. 130:379-391.

Schaeffer, R. N., Mei, Y. Z., Andicoechea, J., Manson, J. S., and Irwin, R. E. 2016. Consequences of a nectar yeast for pollinator preference and performance. Funct. Ecol. 31:613-621.

Sivankalyani, V., Feygenberg, O., Diskin, S., Wright, B., and Alkan, N. 2016a. Increased anthocyanin and flavonoids in mango fruit peel are associated with cold and pathogen resistance. Postharvest Biol. Technol. 111:132-139.

Sivankalyani, V., Sela, N., Feygenberg, O., Zemach, H., Maorer, D., and Alkan, N. 2016b. Transcriptome dynamics in mango fruit peel reveals mechanisms of chilling stress. Front. Plant Sci. 7:1579.

Smith, D. P., and Peay, K. G. 2014. Sequence depth, not PCR replication, improves ecological inference from next generation DNA sequencing. PLoS One 9:e90234.
Stone, J. K., Polishook, J. D., and White, J. F. 2004. Endophytic fungi. Pages 241-270 in: Biodiversity of Fungi. Elsevier Academic Press, Burlington, MA.

Terry, L. A., Mena, C., Williams, A., and Jenney, N., and Whitehead, P. 2011. Fruit and vegetable resource maps. Final Report to WRAP.

Toure, Y., Ongena, M., Jacques, P., Guiro, A., and Thonart, P. 2004. Role of lipopeptides produced by Bacillus subtilis GA1 in the reduction of grey mould disease caused by Botrytis cinerea on apple. J. Appl. Microbiol. 96: 1151-1160.

Vázquez-Baeza, Y., Pirrung, M., Gonzalez, A., and Knight, R. 2013. EMPeror: A tool for visualizing high-throughput microbial community data. Gigascience 2:16.

Vero, S., Garmendia, G., González, M. B., Bentancur, O., and Wisniewski, M. 2013. Evaluation of yeasts obtained from Antarctic soil samples as biocontrol agents for the management of postharvest diseases of apple (Malus domestica). FEMS Yeast Res. 13:189-199.

Zhang, J., Kobert, K., Flouri, T., and Stamatakis, A. 2014. PEAR: A fast and accurate Illumina Paired-End reAd mergeR. Bioinformatics 30:614-620. 